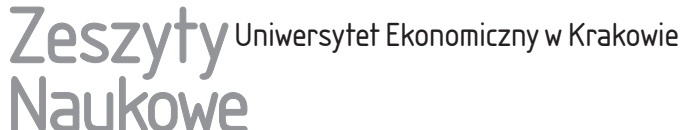

\section{Metodyka zarządzania ryzykiem współpracy z operatorem logistycznym}

\section{Streszczenie}

W artykule zwrócono uwagę, że źródłem ryzyka w działalności przedsiębiorstwa może być obszar współpracy z operatorem logistycznym. Aby przedsiębiorstwo mogło sprawnie funkcjonować, należy zidentyfikować miejsce powstawania tego rodzaju ryzyka oraz ustalić siłę jego oddziaływania.

Istnieje możliwość identyfikowania oraz redukowania negatywnych skutków ryzyka współpracy z operatorem logistycznym przez stosowanie metodyki zarządzania ryzykiem, która umożliwi wskazanie i diagnozę miejsca powstawania ryzyka, określenie jego poziomu oraz doboru właściwych metod postępowania służących do jego ograniczania lub niwelowania. Proponowana procedura pozwala zidentyfikować negatywne zjawiska, umożliwia właściwy przepływ informacji oraz ułatwia ich koordynację. Metodyka zarządzania ryzykiem ma na celu wskazanie tych aspektów współpracy z operatorem logistycznym, które są niezgodne ze standardami i kryteriami ustalonymi wcześniej dla zapewnienia elastycznej współpracy oraz ograniczenia możliwości wzrostu jej kosztów.

Słowa kluczowe: ryzyko, czynniki ryzyka, metodyka zarządzania ryzykiem, operator logistyczny.

Klasyfikacja JEL: L2, L22.

\footnotetext{
Małgorzata Tyrańska, Uniwersytet Ekonomiczny w Krakowie, Wydział Zarządzania, Katedra Procesu Zarządzania, 31-510 Kraków, ul. Rakowicka 27, e-mail: tyranskm@uek.krakow.pl

Tomasz Małkus, Uniwersytet Ekonomiczny w Krakowie, Wydział Zarządzania, Katedra Procesu Zarządzania, 31-510 Kraków, ul. Rakowicka 27, e-mail: malkust@uek.krakow.pl
} 


\section{Wprowadzenie}

Współcześnie problem zarządzania ryzykiem stanowi jedno z najważniejszych zagadnień w zakresie zarządzania przedsiębiorstwem. Rozpoznanie czynników ryzyka i istotności ich wpływu na działalność służy przede wszystkim kształtowaniu w przedsiębiorstwie skutecznych strategii ograniczających niekorzystne oddziaływanie zakłóceń na przebieg procesów produkcyjnych, marketingowych, inwestycyjnych, personalnych, a także logistycznych.

Popularność outsourcingu usług pomocniczych powoduje, że źródeł ryzyka w procesie zarządzania przedsiębiorstwem poszukiwać należy także w obszarze współpracy z operatorem logistycznym (logistics service provider - LSP), a więc z takim przedsiębiorstwem, które świadczy na rzecz swoich klientów kompleksowe usługi związane z przekazywaniem towarów z punktów nadania do miejsc odbioru oraz $\mathrm{z}$ ich składowaniem. $\mathrm{Z}$ założenia współpraca $\mathrm{z}$ operatorem logistycznym ma zapewnić zmniejszenie kosztów zleceniodawcy przez wsparcie zarządzania i organizacji przepływu ładunków. Przyczyn ryzyka współpracy z operatorem logistycznym można zatem upatrywać w niewykonaniu lub niezadowalającym wykonywaniu zleconych usług. Skutki tego ryzyka związane są ze wzrostem zaplanowanych kosztów logistycznych. Do innych czynników, które nasilają ryzyko współpracy z operatorem logistycznym, zaliczyć należy niewystarczające doświadczenie w przygotowywaniu umów, ograniczony dostęp do informacji, skłonność stron do oportunizmu, specyfikę aktywów wykorzystywanych we współpracy, zewnętrzne zmiany warunków związane z przepisami prawnymi, polityką i gospodarką, ale również zjawiska związane z żywiołami naturalnymi, które wpływają na aktywność zleceniodawcy oraz operatora logistycznego.

Celem artykułu jest prezentacja metodyki zarządzania ryzykiem współpracy z operatorem logistycznym. Świadomość tego, że sprawność funkcjonowania przedsiębiorstwa obniżać może ryzyko współpracy z operatorem logistycznym, wymaga identyfikacji miejsca jego powstawania, ustalenia siły oddziaływania ryzyka na przedsiębiorstwo, a także wskazania sposobów redukowania negatywnych skutków ryzyka tej współpracy.

\section{Pojęcie ryzyka współpracy z operatorem logistycznym}

Podobnie jak w teorii zarządzania określa się istotę ryzyka współpracy $\mathrm{z}$ operatorem logistycznym. Ryzyko to wiąże się z osiągnięciem efektów poniżej założonych oczekiwań i dotyczy przede wszystkim niewykonania lub niezadowalającego wykonywania zleconych usług [Weerakkody i Irani 2010]. Dlatego też właściwe kształtowanie regulacji w umowie między klientem a dostawcą usług 
jest postrzegane jako jeden z podstawowych sposobów ograniczenia tego ryzyka. Warunki zawartej umowy określają w szczególności zasady przyjęcia uprawnień i zobowiązań dotyczących realizacji określonych działań, które wiążą się z dostosowaniem do zmian zewnętrznych i wewnętrznych warunków współpracy, ukształtowanie relacji między współpracującymi stronami, a także działania, infrastrukturę i urządzenia, które powinny zostać wykorzystane w adaptacji do współpracy oraz w późniejszej współpracy [Knemeyer, Corsi i Murphy 2003].

Wspomniane zewnętrzne zmiany warunków współpracy dotyczą zwłaszcza prawa, polityki i gospodarki, ale także zjawisk związanych z żywiołami naturalnymi, które wpływają na aktywność zleceniodawcy i operatora logistycznego. Wewnętrzne ryzyko współpracy (dotyczące zachowań stron i relacji między nimi) wynika głównie z wyróżnionych przez O. Williamsona [1985] źródeł kosztów transakcyjnych, czyli z ograniczonej racjonalności (związanej z niewystarczającym doświadczeniem w przygotowywaniu umów, z ograniczeniami w dostępie do informacji), skłonności do oportunizmu oraz specyfiki aktywów wykorzystywanych w ramach współpracy.

Podejmując rozważania dotyczące wyjaśnienia istoty i opisu ryzyka współpracy z operatorem logistycznym, warto wykorzystać podejście, które stworzyli B. Bahli i S. Rivard [2003, s. 213-214]. Ich zdaniem opis ryzyka współpracy powinien zawierać: specyfikację negatywnych scenariuszy, które mogą wystąpić, wyszczególnienie czynników ryzyka mających wpływ na pojawienie się tych scenariuszy, skutki scenariuszy dla zleceniodawcy i usługodawcy, zaprojektowane mechanizmy zmniejszające ryzyko wystąpienia poszczególnych scenariuszy lub - o ile to możliwe - mechanizmów, które pomogą wyeliminować możliwość wystąpienia rozpatrywanego scenariusza.

Osobną kwestię w rozważaniach dotyczących istoty ryzyka we współpracy z operatorem logistycznym stanowi wyodrębnienie różnych typów tego ryzyka. M. Corbett zaproponował ogólny podział ze względu na okres, w którym występują negatywne scenariusze. Wyróżnił następujące rodzaje ryzyka [2004, s. 98]:

- ryzyko transakcyjne - dotyczy uzgodnień co do wypowiedzenia umowy przez strony lub jednostronnego wypowiedzenia umowy, w tym przepisów związanych z rozwiązywaniem sporów, zobowiązań wzajemnych, gwarancji, przekazania aktywów, warunków płatności, jak również kar za niewykonanie lub nienależyte wykonanie umowy;

- ryzyko operacyjne - odnosi się do wpływu współpracy w outsourcingu na pracowników zleceniodawcy, zarówno tych, którzy pozostają w firmie, jak również innych, którzy mogą stać się pracownikami usługodawcy; ten rodzaj ryzyka jest związany z dostosowaniem się usługodawcy do wymagań klienta, ale także z możliwością zmiany reguł współpracy z dostawcą usług; 
- ryzyko strategiczne - dotyczy długofalowych negatywnych skutków współpracy, takich jak: utrata kontroli nad zadaniami zleconymi, utrata know-how, niekorzystne dla klienta zmiany w działalności usługodawcy (np. ograniczenie zakresu świadczonych usług, zmiany w charakterystyce transportu, niedostateczne dostosowanie do zmieniających się przepisów prawa, dotyczących np. przepływów materiałów/towarów niebezpiecznych).

Inną propozycję typologii ryzyka, którą można potraktować jako uzupełnienie typologii przedstawionej wcześniej, przedstawili R. Gonzales, J. Gasco i J. Llopis. Autorzy ci wyróżniają trzy grupy negatywnych scenariuszy, biorąc pod uwagę stronę umowy [2009, s. 187]:

- ryzyko związane z zachowaniem klienta - dotyczy utraty wiedzy technicznej (klienci często nie znają specyfiki konkretnych rodzajów usług, nie znają też architektury ich dostarczania), uzależnienia od dostawcy usług pojawiającego się w trakcie współpracy (nadmierne zaufanie do fachowości dostawcy usług),

- ryzyko związane z dostawcą usług - dotyczy niewystarczających kwalifikacji personelu usługodawcy, braku zgodności działań usługodawcy z umową, braku zdolności jednostki do dostosowania się do nowych technologii,

- ogólne ryzyko współpracy w outsourcingu - dotyczy nieodwracalności decyzji, kosztów ukrytych, niejasnych relacji kosztów i korzyści, bezpieczeństwa informacji, ewentualnego sprzeciwu pracowników.

Warto dodać, że wyróżnienie rodzajów ryzyka w zależności od miejsca jego wystąpienia jest przydatne zwłaszcza w opisie obowiązków i uprawnień stron umowy.

\section{Etapy procesu zarządzania ryzykiem współpracy z operatorem logistycznym}

W warunkach coraz większej złożoności i niepewności otoczenia zasadne jest stosowanie $\mathrm{w}$ przedsiębiorstwie ukierunkowanego postępowania z ryzykiem, czyli zarządzania ryzykiem. Zarządzanie ryzykiem możemy definiować jako: panowanie nad niepewnością, działanie lub praktykę postępowania z ryzykiem, system metod i działań zmierzających do obniżenia stopnia oddziaływania ryzyka na funkcjonowanie podmiotu gospodarczego i do podejmowania w tym celu optymalnych decyzji, skoordynowane działania dotyczące kierowania i nadzorowania organizacji w odniesieniu do ryzyka [Szymonik 2014, s. 128]. Istoty procesu zarządzania ryzykiem współpracy z operatorem logistycznym należy zatem upatrywać z jednej strony w uniknięciu lub ograniczeniu niekorzystnych z punktu widzenia celów przedsiębiorstwa relacji z operatorem logistycznym, a z drugiej w uczynieniu tych relacji bardziej skutecznymi i efektywnymi. W literaturze 


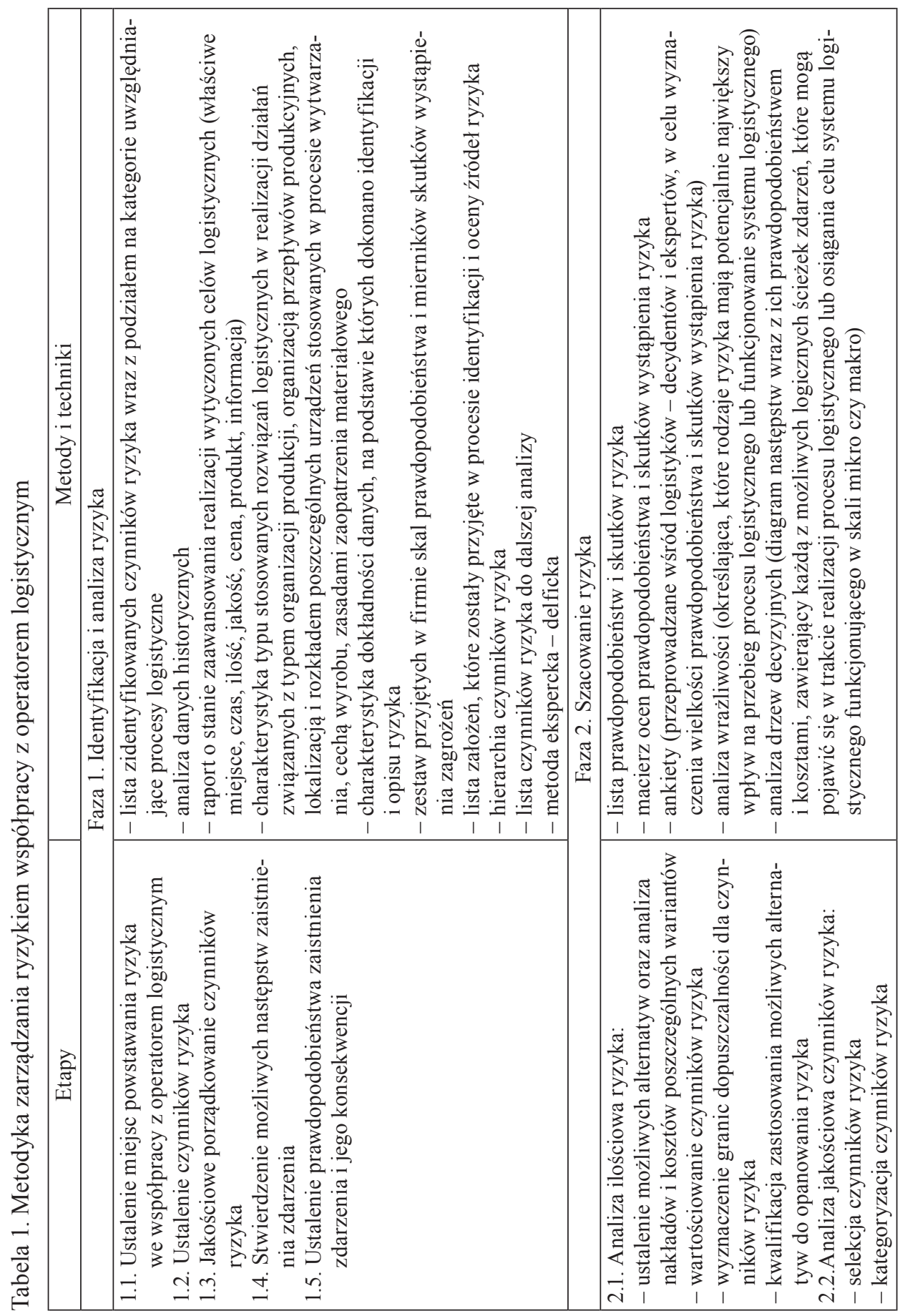




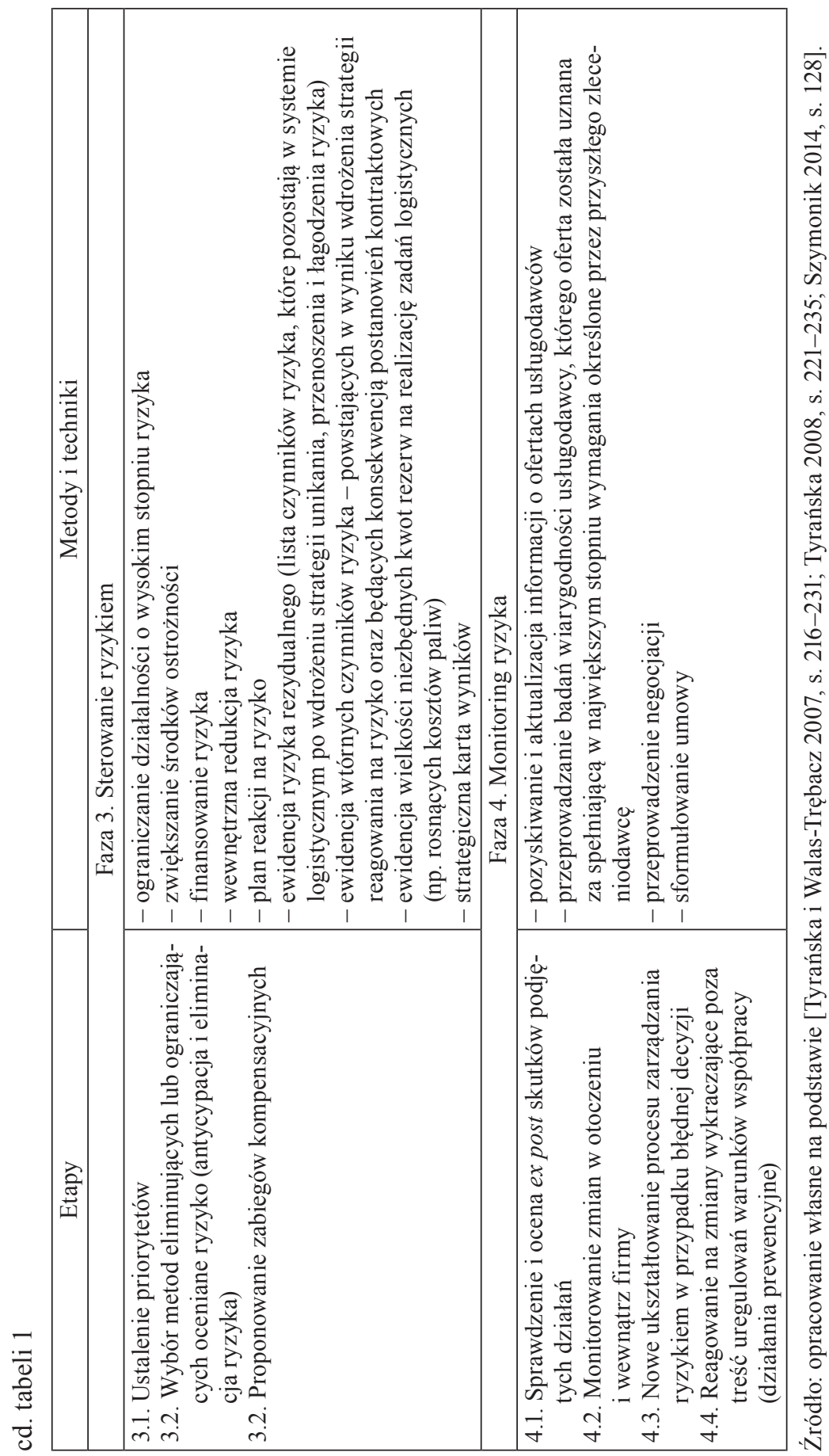


zarządzanie ryzykiem przedstawiane jest jako proces wieloetapowy [Buła 2015, s. 35]. Dlatego też w procesie zarządzania ryzykiem współpracy z operatorem logistycznym wyróżniono następujące fazy: identyfikację ryzyka, szacowanie ryzyka, sterowanie ryzykiem oraz monitoring ryzyka (tabela 1).

\section{Charakterystyka etapów metodyki zarządzania ryzykiem współpracy z operatorem logistycznym}

Identyfikacja ryzyka wyznacza obszar występowania zagrożeń realizowania prawidłowej współpracy z operatorem logistycznym. W efekcie ten etap procesu zarządzania ryzykiem sprowadza się do określenia, jakiego rodzaju zdarzenia mogą być przyczyną powstania negatywnych skutków podejmowanych działań. Dla właściwego rozpoznania ryzyka istotne jest stosowanie usystematyzowanych wcześniej sposobów jego rozpoznania. Rozpoznane i opisane zagrożenia stanowią podstawę do analizy czynników ryzyka, które następnie porządkowane są według określonych kategorii. Przykładem takiego rozwiązania jest tzw. katalog czynników ryzyka współpracy z operatorem logistycznym przedstawiony w tabelach 2 i 3.

\section{Wewnętrzne czynniki ryzyka}

Wykorzystując przedstawioną wcześniej typologię ryzyka współpracy w outsourcingu M. Corbetta [2004], można wyróżnić wewnętrzne czynniki ryzyka we współpracy, charakterystyczne dla wspomnianych typów ryzyka. Dokonując opisu wpływu tych czynników ryzyka na współpracę, należy wyróżnić główne czynniki ryzyka, przykłady negatywnych scenariuszy we współpracy wywołanych przez te czynniki oraz potencjalne skutki dla współpracy. Opisane czynniki ryzyka potraktowano jako najistotniejsze. Zostały one pogrupowane według okresów przygotowania i rozpoczęcia współpracy (czynniki ryzyka transakcyjnego), codziennej współpracy (czynniki ryzyka operacyjnego) oraz współpracy strategicznej (czynniki ryzyka transakcyjnego). Uwzględniono przy tym zróżnicowane założenia zleceniodawców dotyczące znaczenia zleconych usług w strategii działalności, związanego z tym zakresu zlecanych usług logistycznych oraz przewidywanego okresu związania umową. Specyfikę czynników ryzyka w odniesieniu do usług logistycznych odzwierciedlają postawy dostawców i odbiorców zleceniodawcy wobec działalności usługodawcy, który może przejmować obsługę przepływów w ramach zaopatrzenia zleceniodawcy oraz dystrybucji jego produktów do odbiorców. W tych warunkach dostawcy i odbiorcy zleceniodawcy mogą kształtować wizerunek zleceniodawcy na podstawie działań usługodawcy. 
Tabela 2. Katalog czynników ryzyka współpracy z operatorem logistycznym

\begin{tabular}{|c|c|c|}
\hline Czynnik ryzyka & $\begin{array}{c}\text { Scenariusze wywoływane przez } \\
\text { wyróżniony czynnik }\end{array}$ & Skutki dla współpracy \\
\hline \multicolumn{3}{|c|}{ Czynniki ryzyka transakcyjnego w przygotowaniu i uruchamianiu współpracy (Rt) } \\
\hline $\begin{array}{l}\text { Oportunizm usługo- } \\
\text { dawcy }\end{array}$ & $\begin{array}{l}\text { - różnice pomiędzy ofertą usługo- } \\
\text { dawcy a jego rzeczywistą zdol- } \\
\text { nością do wykonania zleconych } \\
\text { usług } \\
\text { - komunikacja dotycząca ryzyka } \\
\text { pomiędzy zleceniodawcą a usłu- } \\
\text { godawcą }\end{array}$ & $\begin{array}{l}\text { - niska jakość świadczonych usług } \\
\text { - niezadowolenie zleceniodawcy, } \\
\text { a także jego dostawców i odbiorców } \\
\text { z realizacji zadań logistycznych } \\
\text { przez usługodawcę (w warunkach } \\
\text { obsługi zaopatrzeniowej i dostaw } \\
\text { do klientów realizowanych przez } \\
\text { usługodawcę) } \\
\text { - konflikty między zleceniodawcą } \\
\text { a usługodawcą niszczące współpracę } \\
\text { - zakłócenia we współpracy związane } \\
\text { z nieprzewidzianymi scenariuszami }\end{array}$ \\
\hline $\begin{array}{l}\text { Asymetria informa- } \\
\text { cji między usługo- } \\
\text { dawcą a zlecenio- } \\
\text { dawcą (dotycząca } \\
\text { zwłaszcza stanu } \\
\text { rynku usług poszu- } \\
\text { kiwanych przez } \\
\text { zleceniodawcę) }\end{array}$ & $\begin{array}{l}\text { - komunikacja dotycząca ryzyka } \\
\text { pomiędzy współpracującymi } \\
\text { partnerami } \\
\text { - różnice pomiędzy ofertą usługo- } \\
\text { dawcy a jego rzeczywistą zdol- } \\
\text { nością do wykonania zleconych } \\
\text { usług }\end{array}$ & $\begin{array}{l}\text { - niska jakość świadczonych usług } \\
\text { - niezadowolenie zleceniodawcy, ale } \\
\text { także jego dostawców i odbiorców } \\
\text { z realizacji zadań logistycznych } \\
\text { przez usługodawcę } \\
\text { - konflikty między zleceniodawcą } \\
\text { a usługodawcą niszczące współpracę } \\
\text { - zakłócenia we współpracy związane } \\
\text { z nieprzewidzianymi scenariuszami }\end{array}$ \\
\hline $\begin{array}{l}\text { Niewystarczające } \\
\text { doświadczenie } \\
\text { zleceniodawcy } \\
\text { w zakresie współ- } \\
\text { pracy z usługo- } \\
\text { dawcą }\end{array}$ & $\begin{array}{l}\text { - niezrozumienie wzajemnych } \\
\text { oczekiwań przez strony umowy } \\
\text { - utrudnienia w określaniu oczeki- } \\
\text { wanych efektów współpracy }\end{array}$ & $\begin{array}{l}\text { - długotrwałe negocjacje z usługo- } \\
\text { dawcą } \\
\text { - konflikty z usługodawcą, zwłaszcza } \\
\text { na etapie konsultacji i przygotowania } \\
\text { umowy } \\
\text { - niska jakość usług }\end{array}$ \\
\hline $\begin{array}{l}\text { Różnice w zakresie } \\
\text { kultury organi- } \\
\text { zacyjnej między } \\
\text { zleceniodawcą } \\
\text { a usługodawcą }\end{array}$ & $\begin{array}{l}\text { - niezrozumienie wzajemnych } \\
\text { oczekiwań przez strony umowy }\end{array}$ & $\begin{array}{l}\text { - długotrwałe negocjacje z usługo- } \\
\text { dawcą } \\
\text { - konflikty z usługodawcą, zwłaszcza } \\
\text { na etapie konsultacji i przygotowania } \\
\text { umowy } \\
\text { - niska jakość usług }\end{array}$ \\
\hline $\begin{array}{l}\text { Brak podziału odpo- } \\
\text { wiedzialności za } \\
\text { aktualizację infor- } \\
\text { macji o rynku usług } \\
\text { między pracowni- } \\
\text { ków zleceniodawcy }\end{array}$ & $\begin{array}{l}\text { - brak wiedzy o aktualnym stanie } \\
\text { rynku usług i związane z tym } \\
\text { nadmierne koszty uzyskania } \\
\text { oczekiwanej jakości usług (jeżeli } \\
\text { na rynku występują jednostki, } \\
\text { które oferują podobną jakość za } \\
\text { niższą cenę) }\end{array}$ & $\begin{array}{l}\text { - utrudnienia w poszukiwaniu usłu- } \\
\text { godawcy spełniającego oczekiwania } \\
\text { zleceniodawcy } \\
\text { - straty czasu w przypadku koniecz- } \\
\text { ności zmiany usługodawcy }\end{array}$ \\
\hline
\end{tabular}


cd. tabeli 2

\begin{tabular}{|c|c|c|}
\hline Czynnik ryzyka & $\begin{array}{c}\text { Scenariusze wywoływane przez } \\
\text { wyróżniony czynnik }\end{array}$ & Skutki dla współpracy \\
\hline $\begin{array}{l}\text { Różnice w postrze- } \\
\text { ganiu ryzyka przez } \\
\text { strony umowy }\end{array}$ & $\begin{array}{l}\text { - problemy w komunikowaniu } \\
\text { dotyczącym ryzyka pomiędzy } \\
\text { partnerami }\end{array}$ & $\begin{array}{l}\text { - zakłócenia w realizacji współpracy } \\
\text { i związane z tym konflikty z usłu- } \\
\text { godawcą }\end{array}$ \\
\hline \multicolumn{3}{|c|}{ Czynniki ryzyka operacyjnego we współpracy z usługodawcą (Ro) } \\
\hline $\begin{array}{l}\text { Specyfika aktywów } \\
\text { (często związana } \\
\text { także z ograniczoną } \\
\text { dostępnością jedno- } \\
\text { stek usługowych) }\end{array}$ & $\begin{array}{l}\text { - nadmierne uzależnienie od usłu- } \\
\text { godawcy }\end{array}$ & $\begin{array}{l}\text { - niska jakość nabywanych usług } \\
\text { - utrata niezależności rynkowej przez } \\
\text { zleceniodawcę }\end{array}$ \\
\hline $\begin{array}{l}\text { Oportunizm usługo- } \\
\text { dawcy }\end{array}$ & $\begin{array}{l}\text { - nadmierne uzależnienie od usłu- } \\
\text { godawcy } \\
\text { - konflikty między stronami skut- } \\
\text { kujące oddaniem sprawy do sądu }\end{array}$ & $\begin{array}{l}\text { - niska jakość świadczonych usług } \\
\text { - utrata wypracowanego korzystnego } \\
\text { wizerunku u dostawców i odbior- } \\
\text { ców (jeżeli usługodawca dostarcza } \\
\text { towary do zleceniodawcy od dostaw- } \\
\text { ców i realizuje dostawy do jego } \\
\text { odbiorców) }\end{array}$ \\
\hline $\begin{array}{l}\text { Asymetria informa- } \\
\text { cji między zlece- } \\
\text { niodawcą a usługo- } \\
\text { dawcą }\end{array}$ & $\begin{array}{l}\text { - niewystarczająca wiedza zlece- } \\
\text { niodawcy o jakości usług } \\
\text { - problemy dotyczące zarządzania } \\
\text { kooperacją (zwłaszcza uzgadnia- } \\
\text { nia tej kooperacji z usługodawcą) } \\
\text { - konflikty z usługodawcą roz- } \\
\text { strzygane przez sądy }\end{array}$ & $\begin{array}{l}\text { - wysokie koszty zmian usługodawcy } \\
\text { oraz zarządzania współpracą } \\
\text { - zakłócenia (a nawet przerwy) } \\
\text { w działalności zleceniodawcy }\end{array}$ \\
\hline $\begin{array}{l}\text { Niewystarczające } \\
\text { doświadczenie } \\
\text { zleceniodawcy doty- } \\
\text { czące współpracy } \\
\text { z usługodawcą }\end{array}$ & $\begin{array}{l}\text { - nadmierne uzależnienie od usłu- } \\
\text { godawcy } \\
\text { - występowanie problemów doty- } \\
\text { czących zarządzania kooperacją } \\
\text { (zwłaszcza uzgadniania tej } \\
\text { kooperacji z usługodawcą) } \\
\text { - konflikty z usługodawcą skutku- } \\
\text { jące oddaniem sprawy do sądu }\end{array}$ & $\begin{array}{l}\text { - niska jakość usług } \\
\text { - nieporozumienia i konflikty między } \\
\text { zleceniodawcą a usługodawcą oraz } \\
\text { między usługodawcą a innymi } \\
\text { jednostkami współpracującymi } \\
\text { ze zleceniodawcą } \\
\text { - wysokie koszty zarządzania współ- } \\
\text { pracą } \\
\text { - zakłócenia we współpracy, wpły- } \\
\text { wające na zakłócenia i przerwy } \\
\text { w działaniach zleceniodawcy }\end{array}$ \\
\hline $\begin{array}{l}\text { Zależności przy- } \\
\text { czynowo-skutkowe } \\
\text { między działaniami } \\
\text { zleceniodawcy } \\
\text { i usługodawcy }\end{array}$ & $\begin{array}{l}\text { - długi czas koordynowania } \\
\text { działań, wspólnego rozwiązy- } \\
\text { wania problemów, obustronnego } \\
\text { dostosowywania się }\end{array}$ & $\begin{array}{l}\text { - zakłócenia we współpracy wpływa- } \\
\text { jące na zakłócenia i przerwy w dzia- } \\
\text { łaniach zleceniodawcy (zatrzymanie } \\
\text { przepływu towarów) } \\
\text { - wysokie koszty koordynowania } \\
\text { współpracy }\end{array}$ \\
\hline
\end{tabular}


cd. tabeli 2

\begin{tabular}{|c|c|c|}
\hline Czynnik ryzyka & $\begin{array}{c}\text { Scenariusze wywoływane przez } \\
\text { wyróżniony czynnik }\end{array}$ & Skutki dla współpracy \\
\hline \multicolumn{3}{|c|}{ Czynniki ryzyka strategicznego we współpracy z usługodawcą (Rs) } \\
\hline $\begin{array}{l}\text { Oportunizm usługo- } \\
\text { dawcy }\end{array}$ & $\begin{array}{l}\text { - utrata kontroli nad zleconą dzia- } \\
\text { łalnością } \\
\text { - nadmierne uzależnienie strategii } \\
\text { zleceniodawcy od usługodawcy }\end{array}$ & $\begin{array}{l}\text { - niepewność dotycząca jakości wyko- } \\
\text { nania zleconych zadań } \\
\text { - utrata samodzielności rynkowej } \\
\text { przez zleceniodawcę } \\
\text { - brak zdolności do samodzielnego } \\
\text { kształtowania strategii przez zlece- } \\
\text { niodawcę (bez konsultacji z usługo- } \\
\text { dawcą) } \\
\text { - niepewność dotycząca jakości } \\
\text { wyników realizacji działalności } \\
\text { podstawowej prowadzonej przez } \\
\text { zleceniodawcę (zależnie od skali } \\
\text { wpływu działań usługodawcy na tę } \\
\text { działalność) }\end{array}$ \\
\hline $\begin{array}{l}\text { Niewystarczające } \\
\text { mechanizmy kontro- } \\
\text { lowania działań } \\
\text { usługodawcy przez } \\
\text { zleceniodawcę }\end{array}$ & $\begin{array}{l}\text { - utrata kontroli nad zleconą dzia- } \\
\text { łalnością }\end{array}$ & $\begin{array}{l}\text { - niepewność dotycząca jakości wyko- } \\
\text { nania zleconych zadań } \\
\text { - utrata samodzielności rynkowej } \\
\text { przez zleceniodawcę } \\
\text { - niepewność dotycząca jakości } \\
\text { wyników realizacji działalności } \\
\text { podstawowej prowadzonej przez } \\
\text { zleceniodawcę }\end{array}$ \\
\hline $\begin{array}{l}\text { Niewystarczające } \\
\text { doświadczenie } \\
\text { zleceniodawcy we } \\
\text { współpracy z usłu- } \\
\text { godawcami }\end{array}$ & $\begin{array}{l}\text { - utrata kontroli nad zleconą dzia- } \\
\text { łalnością } \\
\text { - nadmierne uzależnienie strategii } \\
\text { zleceniodawcy od usługodawcy }\end{array}$ & $\begin{array}{l}\text { - niepewność dotycząca jakości wyko- } \\
\text { nania zleconych zadań } \\
\text { - utrata samodzielności rynkowej } \\
\text { przez zleceniodawcę } \\
\text { - brak zdolności do samodzielnego } \\
\text { kształtowania strategii prowadzonej } \\
\text { przez zleceniodawcę (bez konsultacji } \\
\text { z usługodawcą) }\end{array}$ \\
\hline $\begin{array}{l}\text { Niewystarczające } \\
\text { zaangażowanie usłu- } \\
\text { godawcy w dosko- } \\
\text { nalenie współpracy }\end{array}$ & $\begin{array}{l}\text { - niewystarczający rozwój lub brak } \\
\text { rozwoju działalności zlecenio- } \\
\text { dawcy }\end{array}$ & $\begin{array}{l}\text { - osłabienie pozycji rynkowej zlece- } \\
\text { niodawcy } \\
\text { - utrudnienia w planowaniu działalno- } \\
\text { ści zleceniodawcy }\end{array}$ \\
\hline $\begin{array}{l}\text { Błędne określenie } \\
\text { zakresu działalno- } \\
\text { ści podstawowej } \\
\text { (związane ze zbyt } \\
\text { szerokim zakresem } \\
\text { zleconych usług) }\end{array}$ & $\begin{array}{l}\text { - utrata know-how } \\
\text { - nadmierne uzależnienie od dzia- } \\
\text { łalności usługodawcy } \\
\text { - brak samodzielności w kształto- } \\
\text { waniu strategii przez zlecenio- } \\
\text { dawcę }\end{array}$ & $\begin{array}{l}\text { - osłabienie pozycji rynkowej } \\
\text { - niepewność dotycząca jakości wyko- } \\
\text { nania zleconych zadań } \\
\text { - utrata samodzielności rynkowej } \\
\text { przez zleceniodawcę } \\
\text { - brak zdolności do samodzielnego } \\
\text { kształtowania strategii przez zlece- } \\
\text { niodawcę }\end{array}$ \\
\hline
\end{tabular}

Źródło: [Małkus 2013]. 
Zewnętrzne czynniki ryzyka

Jako punkt wyjścia w rozważaniach dotyczących zewnętrznych czynników ryzyka współpracy z operatorem logistycznym (Rz) można potraktować uniwersalny (niezależny od rodzajów zleconych usług) problem niepożądanych zachowań usługodawcy związany z wpływem innych zleceniodawców, z którymi ten usługodawca współpracuje. Uwzględniając charakterystykę działalności wspomnianych zleceniodawców, którzy mogą być konkurentami względem siebie oraz wobec zleceniodawcy, należy zwrócić uwagę na istotny czynnik ryzyka, jakim jest nielojalność usługodawcy wobec poszczególnych zleceniodawców, polegająca na:

- udostępnianiu informacji o osiągnięciach konkurentom pod wpływem nacisków wywieranych przez zleceniodawców na usługodawcę,

- kopiowaniu rozwiązań dotyczących obsługi przepływu towarów wypracowanych z konkretnym zleceniodawcą we współpracy z jego konkurentami,

- nieformalnym porozumieniu usługodawcy z wybranym zleceniodawcą, skutkujące ograniczaniem dostępu pozostałych zleceniodawców do świadczonych usług (szczególnie istotne w przypadku wysokiej specyfiki aktywów występujących we współpracy).

Należy dodać, że jakkolwiek przedstawione przykłady zachowań usługodawcy mogą wystąpić niezależnie od rodzajów świadczonych usług, to z punktu widzenia rozwiązań logistycznych mają one szczególny charakter. Wynika to $\mathrm{z}$ aktualnego znaczenia logistyki w osiąganiu przewagi konkurencyjnej przez przedsiębiorstwa. W warunkach współpracy strategicznej z dostawcą usług logistycznych, która oparta jest na obustronnych korzyściach ze współpracy, a często także na wspólnych inwestycjach, zachowanie poufności we współpracy jest szczególnie ważne. Zachowania polegające na niepożądanym udostępnianiu informacji innym jednostkom mogą znacząco wpływać na konkurencyjność zleceniodawców.

Ponadto może pojawić się trudność w odróżnieniu rozwiązań stosowanych przez usługodawcę, które są efektem uczenia się tej jednostki w zakresie obsługi konkretnego sektora, od niepożądanego kopiowania rozwiązań wypracowanych z jednym zleceniodawcą w innych transakcjach. Szczególne znaczenie mają w tym przypadku postanowienia umów pomiędzy wspomnianym usługodawcą a każdym z jego zleceniodawców.

Obok przedstawionych dotychczas czynników, wynikających z relacji pomiędzy usługodawcą a jego zleceniodawcami oraz pomiędzy zleceniodawcami, warto zwrócić uwagę także na inne uniwersalne czynniki, występujące w otoczeniu wspomnianych jednostek (tabela 3 ). 
Tabela 3. Uniwersalne czynniki występujące w otoczeniu partnerów logistycznych

\begin{tabular}{|c|c|}
\hline Czynnik ryzyka & Przykłady \\
\hline Rozwój techniczno-technologiczny & $\begin{array}{l}\text { Wpływa na usprawnianie działalności logistycznej, ale } \\
\text { także na inne dziedziny działalności przedsiębiorstwa, } \\
\text { np. rozwój narzędzi informatycznego wspomagania } \\
\text { zarządzania zasobami przedsiębiorstwa }\end{array}$ \\
\hline $\begin{array}{l}\text { Zmiany obowiązujących w Polsce } \\
\text { przepisów prawa dotyczących } \\
\text { dziedziny działalności, która jest } \\
\text { przedmiotem współpracy }\end{array}$ & $\begin{array}{l}\text { Ruch drogowy, transport drogowy, kolejowy, lotniczy } \\
\text { i morski; usuwanie odpadów, surowców wtórnych; prze- } \\
\text { wóz i składowanie materiałów niebezpiecznych }\end{array}$ \\
\hline $\begin{array}{l}\text { Zmiany w regulacjach międzynaro- } \\
\text { dowych }\end{array}$ & $\begin{array}{l}\text { Umowy dotyczące dokumentacji międzynarodowego } \\
\text { przewozu drogowego towarów - CMR, ADR (w zakre- } \\
\text { sie przepływu towarów niebezpiecznych) }\end{array}$ \\
\hline $\begin{array}{l}\text { Zmiany charakterystyki preferencji } \\
\text { klientów }\end{array}$ & Zmiana popytu \\
\hline Rozwój rynku usług logistycznych & $\begin{array}{l}\text { Pojawianie się nowych usługodawców, rozwój ofert } \\
\text { dotychczasowych jednostek, łączenie się przedsię- } \\
\text { biorstw w celu zwiększenia siły konkurencyjnej }\end{array}$ \\
\hline $\begin{array}{l}\text { Ingerencja w infrastrukturę drogową } \\
\text { i kolejową }\end{array}$ & $\begin{array}{l}\text { Ingerencja skutkująca wydłużeniem dróg przewozu, } \\
\text { związanymi z tym opóźnieniami w stosunku do założeń } \\
\text { planów sprzed okresu, w którym rozpoczęto remonty }\end{array}$ \\
\hline $\begin{array}{l}\text { Zmiany organizacji rynków niektó- } \\
\text { rych usług }\end{array}$ & $\begin{array}{l}\text { Podziały przedsiębiorstw na rynku transportu kolejo- } \\
\text { wego w Polsce }\end{array}$ \\
\hline $\begin{array}{l}\text { Zmiany w uwarunkowaniach prze- } \\
\text { wozów lotniczych }\end{array}$ & $\begin{array}{l}\text { Powstawanie nowych portów lotniczych skutkujące } \\
\text { większą dostępnością tych usług }\end{array}$ \\
\hline
\end{tabular}

Źródło: opracowanie własne na podstawie [Małkus 2013].

Warto podkreślić, że na wymienione w tabeli 3 czynniki, występujące w otoczeniu współpracy, zasadniczo nie ma wpływu żadna ze stron współpracy. Tego typu czynniki ryzyka współpracy mogą być ujęte w umowie zleceniodawcy z usługodawcą jako tzw. plany awaryjne, stosowane w przypadku wystąpienia zmian w otoczeniu oraz przez pozostawienie możliwości renegocjowania warunków współdziałającym stronom.

Szacowanie poziomu ryzyka umożliwia dokonanie analizy wartościującej poszczególnych rodzajów ryzyka współpracy z operatorem logistycznym. Rezultatem tej analizy jest ustalenie poziomu prawdopodobieństwa wystąpienia negatywnego zjawiska oraz rozmiaru strat, które może ono wywołać. Całkowite ryzyko współpracy z operatorem logistycznym (Rwol) stanowi iloczyn ryzyka transakcyjnego (Rt), ryzyka operacyjnego (Ro), ryzyka strategicznego (Rs) i ryzyka zewnętrznego $(\mathrm{Rz})$.

W szacowaniu poziomu ryzyka współpracy z operatorem logistycznym posłużyć się można metodą standardowej oceny ryzyka [Bizon-Górecka 2001, s. 67]. 
Zastosowanie tej metody obejmuje: określenie głównych możliwych zdarzeń ryzykownych we współpracy z operatorem logistycznym, szacowanie prawdopodobieństwa wystąpienia poszczególnych zjawisk, ocenę skutków tych zjawisk, obliczenie iloczynu obydwu wielkości i ustalenie ostatecznej oceny poziomu ryzyka współpracy z operatorem logistycznym. W odniesieniu do każdego zidentyfikowanego prawdopodobieństwa należy - w drodze odrębnej analizy - ocenić wpływ potencjalnych skutków jego wystąpienia. Skutki te należy ocenić w aspekcie ilościowym i jakościowym. Stosując proponowaną metodę, respondenci (kadra kierownicza, eksperci) szacują indywidualnie prawdopodobieństwo wystąpienia każdego negatywnego zdarzenia (NZ) i skalę jego skutków (OS). Zastosowanie tych dwóch kryteriów łącznie pozwala ukierunkować proces zarządzania ryzykiem współpracy z operatorem logistycznym na czynniki o najwyższym wpływie i jednocześnie o najwyższym prawdopodobieństwie. Następnie oblicza się średnie wielkości z indywidualnych szacunków oraz poziom ryzyka (PR) dla każdego negatywnego zdarzenia, który stanowi iloczyn prawdopodobieństwa wystąpienia każdego negatywnego zdarzenia (NZ) i skali jego skutków (OS). Jeśli obliczony wskaźnik nie przekracza wartości 0,1 , mówimy o niskim poziomie ryzyka (N). Wartość $0,1-0,5$ oznacza średni poziom ryzyka (S), a ponad 0,5 - wysoki poziom ryzyka (W). Wartość wskaźnika obrazuje uświadamiany przez badanych poziom ryzyka dla wskazanych negatywnych zjawisk w różnych obszarach współpracy z operatorem logistycznym. Na tej podstawie, uśredniając wartości ryzyka wynikające z poszczególnych negatywnych zjawisk określonych dla danego obszaru współpracy z operatorem logistycznym, można ustalić poziom ryzyka dla tego obszaru. Takie działania umożliwią porównanie poziomu ryzyka w poszczególnych latach lub porównanie sposobu realizacji współpracy logistycznej i związanego z nią ryzyka wynikającego ze współpracy z różnymi operatorami logistycznymi.

Efektem przeprowadzenia analizy ilościowej ryzyka dla realizacji celów systemu logistycznego, np. centrum dystrybucyjnego czy firmy transportowej, może być analiza probabilistyczna (zawiera prognozy dotyczące kosztów logistycznych i czasów realizacji zadań), określenie wielkości prawdopodobieństwa osiągnięcia celów kosztów logistycznych i czasowych lub określenie trendów charakteryzujących wyniki ilościowej analizy ryzyka (takie informacje można uzyskać na podstawie kilkukrotnego przeprowadzenia analizy ilościowej). Rezultatem planowanych reakcji na ryzyko jest proces opracowywania wariantów postępowania i czynności zmniejszających zagrożenia i zwiększających potencjalne korzyści w zakresie procesów i systemów logistycznych [Szymonik 2014, s. 132]. Takie podejście wydaje się przydatne również w warunkach wspomagania działalności logistycznej zleceniodawcy przez operatora logistycznego. 
Sterowanie ryzykiem umożliwia ustalenie priorytetowych działań eliminujących lub ograniczających oceniane ryzyko, a w konsekwencji usprawniających realizację współpracy z operatorem logistycznym. Na tym etapie procesu zarządzania ryzykiem można wykorzystać strategiczną kartę wyników. Argumenty przymawiające za jej zastosowaniem są następujące: metoda ta stanowi system pomiaru, który pozwala ocenić istotę współpracy logistycznej z punktu widzenia strategii przedsiębiorstwa, i zawiera najważniejsze z punktu widzenia celów strategicznych miary, między którymi występują związki przyczynowo-skutkowe. Metoda ta wskazuje na potrzebę podjęcia działań naprawczych w wybranych obszarach działalności logistycznej przedsiębiorstwa, informuje o przyszłych dokonaniach przedsiębiorstwa w zakresie realizacji zadań logistycznych. W strategicznej karcie wyników opracowanej dla całego przedsiębiorstwa można w poszczególnych perspektywach, a zwłaszcza w perspektywie procesów wewnętrznych, odnaleźć wskaźniki właściwe dla pomiaru efektywności zarządzania logistyką przeprowadzanego z punktu widzenia oceny realizacji strategii przedsiębiorstwa. Wykorzystanie strategicznej karty wyników w procesie sterowania ryzykiem współpracy z operatorem logistycznym umożliwi usprawnienie działań w obszarze logistycznym oraz zapewni skuteczniejszą realizację strategii przedsiębiorstwa.

Ponieważ czynniki ryzyka nierzadko zmieniają się w czasie, monitoring ryzyka stanowi ważny element kontroli współpracy z operatorem logistycznym. Monitorowanie ryzyka to zbiór działań, do których należy bieżące śledzenie aktualnych i potencjalnych źródeł ryzyka, weryfikacja prawdopodobieństwa pojawienia się niekorzystnych zdarzeń oraz badanie efektywności środków zapobiegawczych [Stabryła, Cabała i Sołtysik 2015, s. 220].

Celem monitoringu ryzyka współpracy logistycznej jest dostarczanie informacji zwrotnej, dzięki której możliwa jest efektywna adaptacja warunków tej współpracy do zmiennych warunków działania kooperujących ze sobą przedsiębiorstw. Duże znaczenie w realizacji tej funkcji zarządzania ryzykiem ma system raportowania, który jest ukierunkowany na bieżącą charakterystykę symptomów występujących zagrożeń we współpracy logistycznej oraz opis podjętych działań zapobiegawczych.

Wszystkie krytyczne lub ważne rodzaje ryzyka należy monitorować przez cały okres trwania współpracy logistycznej. Działania mające na celu ograniczenie ryzyka współpracy mogą dotyczyć tworzenia wstępnego rankingu usługodawców wykorzystywanego przez zleceniodawcę w przypadku potrzeby zmiany dotychczasowego kooperanta. W tabeli 6 przedstawiono działania, które można dodatkowo podjąć w celu ograniczenia ryzyka związanego ze współpracą $\mathrm{z}$ wyspecjalizowaną jednostką logistyczną. 
Tabela 6. Działania i metody ograniczania ryzyka współpracy z operatorem logistycznym

\begin{tabular}{|c|c|}
\hline Działanie & Metody \\
\hline $\begin{array}{l}\text { Pozyskiwanie informacji } \\
\text { o ofertach usługodawców }\end{array}$ & $\begin{array}{l}\text { - zapytanie o ofertę } \\
\text { - zapytanie o cenę } \\
\text { - list intencyjny } \\
\text { - umowa przedwstępna }\end{array}$ \\
\hline $\begin{array}{l}\text { Przeprowadzanie badań } \\
\text { wiarygodności usługo- } \\
\text { dawcy, którego oferta } \\
\text { została potraktowana jako } \\
\text { spełniająca w najwięk- } \\
\text { szym stopniu wymagania } \\
\text { określone przez przyszłego } \\
\text { zleceniodawcę }\end{array}$ & $\begin{array}{l}\text { - rekomendacja od innych zleceniodawców } \\
\text { - historia współpracy z dotychczasowymi zleceniodawcami }\end{array}$ \\
\hline Przeprowadzenie negocjacji & $\begin{array}{l}\text { - na etapie otwierania negocjacji: ustalenie kolejności dyskutowa- } \\
\text { nych kwestii, np. najważniejsze i sporne na początek, przedsta- } \\
\text { wienie propozycji, technika „mierz wysoko”, ,próbny balon” } \\
\text { w celu uzyskania informacji o wyjściowych wymaganiach } \\
\text { drugiej strony, odrzucanie pierwszej oferty } \\
\text { - na etapie negocjacji właściwych: techniki integratywne (reduk- } \\
\text { cja, kompensacja kosztów, dopasowanie, łączenie interesów), } \\
\text { technika sytuacji hipotetycznej (co by było gdyby?), opóźnianie } \\
\text { - na etapie zamykania negocjacji: działania prewencyjne (wprowa- } \\
\text { dzanie celu nadrzędnego dla stron, absorpcja protestu, perswa- } \\
\text { zja w celu wykazania korzyści). Wyniki negocjacji mogą być } \\
\text { zestawione w protokole porozumienia stanowiącym podstawę } \\
\text { opracowania przyszłej umowy }\end{array}$ \\
\hline Formułowanie umowy & $\begin{array}{l}\text { - regulacje prawne Unii Europejskiej, w których przewidziano } \\
\text { możliwość uzyskania przez przedsiębiorstwa tzw. statusu przed- } \\
\text { siębiorcy uprzywilejowanego (authorized economic operator } \\
\text { - AEO) } \\
\text { - zalecenia opracowane przez Komisję ds. Bezpieczeństwa w Łań- } \\
\text { cuchu Dostaw przy Polskiej Izbie Spedycji i Logistyki opubli- } \\
\text { kowane na stronie internetowej Izby, dotyczące kształtowania } \\
\text { postaw i postępowania spedytorów } \\
\text { - gwarancja jakości świadczonych usług (service level agreement } \\
\text { - SLA) } \\
\text { - umowy nazwane występujące w kodeksie cywilnym: spedycji, } \\
\text { przewozu, składu, dostawy } \\
\text { - propozycja międzynarodowych warunków (terminów) handlo- } \\
\text { wych (international commercial terms - Incoterms) } \\
\text { - standardy przygotowania i realizacji działań spedycyjnych, } \\
\text { określone jako ogólne polskie warunki spedycji (OPWS) opraco- } \\
\text { wane przez Polską Izbę Spedycji i Logistyki, dotyczące spedycji } \\
\text { krajowej i międzynarodowej }\end{array}$ \\
\hline
\end{tabular}

Źródło: opracowanie własne na podstawie [Kozina 2004, s. 107; Rozporządzenie (WE) nr 648/2005...; Vademecum... 2013; Bendor-Samuel 1997, s. 36; Stuglik 2010]. 
W przedstawionych dotychczas rozważaniach nie uwzględniono jednak problemu ograniczania skłonności usługodawcy do oportunizmu i wykorzystywania asymetrii informacji oraz specyfiki aktywów (zwłaszcza wysokiej) dla własnych celów. W warunkach podejmowania współpracy związanej ze zlecaniem usługodawcy wąskiego zakresu zadań pomocniczych kwestia motywowania tej jednostki ma niewielkie znaczenie. Wynika to zazwyczaj z łatwości zmiany usługodawcy, jeśli dotychczasowy nie spełni oczekiwań zleceniodawcy. Budowanie partnerskich relacji pomiędzy stronami odgrywa znacznie istotniejszą rolę $\mathrm{w}$ warunkach przewidywanego długiego okresu współpracy z usługodawcą, opartej na obustronnych korzyściach i polegającej na kompleksowej obsłudze zleceniodawcy. W takich przypadkach szczególne znaczenie mają uregulowania $\mathrm{w}$ umowie związane $\mathrm{z}$ motywowaniem usługodawcy, takie jak: udział w dodatkowych korzyściach zleceniodawcy, możliwość rozszerzania zakresu zleconych usług, możliwość zmiany rozdziału ilości usług dla grupy jednostek realizujących te same zadania dla zleceniodawcy, dodatkowe korzyści z wdrożonych usprawnień w działalności zleceniodawcy, wspólne inwestycje z podziałem korzyści. Regulacje takie, oprócz ograniczenia nadzoru wykonania zadań przez usługodawcę i pozostawiania tej jednostce pewnego zakresu samodzielności w określaniu sposobów wykonania zleconych zadań, mogą dać poczucie partnerstwa we współpracy. Założenie o długim okresie trwania współpracy oraz perspektywa dodatkowych korzyści płynących z tej współpracy może pozwolić ograniczyć skłonność usługodawcy do postaw oportunistycznych.

W warunkach dynamicznego otoczenia monitoringowi przypisuje się szczególną rolę. Mówi się wręcz o tym, że jest on niezbędny w procesie zarządzania, gdyż nawet prawidłowo zaplanowane cele i środki w dobrze ukształtowanych strukturach nie są w stanie uchronić przedsiębiorstwa przed wystąpieniem niezamierzonych, często niepożądanych skutków przyjętych wcześniej rozwiązań. Wśród innych korzyści, które mogą pojawić się w wyniku zastosowania monitoringu ryzyka współpracy z operatorem logistycznym, wskazać można: wyróżnienie specyficznych typów ryzyka, określenie wielkości szkód (kosztów), które mogą wywołać, określenie granic dopuszczalnego i tolerowanego ryzyka, możliwość szybkiej reakcji (podjęcia działań obronnych) po przekroczeniu tolerowanych granic ryzyka (ograniczenie liczby zdarzeń przypadkowych i losowych przez wskazanie kierunków dalszych działań w sytuacji, kiedy nie ma pewności co do przyszłego rozwoju wypadków), wzbogacenie metod współpracy z operatorem logistycznym o metody zarządzania ryzykiem. 


\section{Podsumowanie}

Ryzyko, które jest nieodłącznym elementem współpracy z operatorem logistycznym, należy zaliczyć do ważnych, choć równocześnie nie do końca rozpoznanych problemów. Jego skala i determinanty wynikają ze specyfiki podjętej współpracy. Ze względu na nieprzewidywalność niektórych zjawisk oraz niemożność określenia ich wpływu na realizację współpracy z operatorem logistycznym kierownictwo przedsiębiorstwa może podjąć próby minimalizacji wystąpienia ryzyka, ponieważ ono zawsze istnieje.

Zmniejszenie negatywnych skutków ryzyka współpracy jest możliwe przez stosowanie procedury zarządzania ryzykiem. Procedura ta umożliwia identyfikację i analizę miejsca powstawania ryzyka, określenie jego poziomu oraz doboru właściwych metod postępowania służących do jego ograniczania lub niwelowania. Pozwoli ona zidentyfikować negatywne zjawiska, umożliwi właściwy przepływ informacji oraz ułatwi ich koordynację. Procedura zarządzania ryzykiem wskazuje te aspekty współpracy z operatorem logistycznym, które są niezgodne ze standardami i kryteriami ustalonymi wcześniej w celu zapewnienia elastycznej współpracy.

Istotnym ograniczeniem związanym z wdrożeniem prezentowanej metodyki zarządzania ryzykiem współpracy z operatorem logistycznym jest brak sprawdzonych wzorcowych rozwiązań systemowych, które tylko przy niewielkich modyfikacjach mogłyby być wykorzystywane przez wszystkie tego rodzaju podmioty. Dodatkowym utrudnieniem jest fakt, że ryzyko to ma charakter wielowymiarowy. Tylko niewielka część czynników ryzyka poddaje się kwantyfikacji. Ponadto ocena ryzyka ma często charakter subiektywny. Umiejętność zarządzania ryzykiem współpracy z operatorem logistycznym jest także w znacznym stopniu uzależniona od doświadczenia decydentów, zarówno po stronie zleceniodawcy, jak również po stronie usługodawcy.

Podsumowując, należy stwierdzić, że w czasach dynamicznych zmian następujących w otoczeniu współpracujące podmioty powinny stworzyć odpowiednie komórki odpowiedzialne za realizację procesu zarządzania ryzykiem. Działania takie nie powinny wynikać wyłącznie z chęci uniknięcia potencjalnych zagrożeń, ale powinny być też podyktowane dążeniem obu współpracujących ze sobą podmiotów do podniesienia jakości świadczonych usług.

Przedmiotem dalszych poszukiwań, mających na celu zwiększenie praktycznej przydatności przedstawionej metodyki, może być rozróżnienie istotności poszczególnych czynników ryzyka dla zleceniodawcy i usługodawcy, a także wyodrębnienie kluczowych czynników ryzyka w zależności od zakresu współpracy logistycznej i związanego z tym poziomu integracji działań obu stron. 
Biorąc pod uwagę wielowymiarowy charakter ryzyka współpracy logistycznej, istotne może być także określenie możliwości agregowania oceny ryzyka.

Poszukiwania teoretyczne mogą z kolei dotyczyć określania wpływu zaufania pomiędzy reprezentantami zleceniodawcy i usługodawcy na podejmowanie działań dotyczących redukcji wpływu zwłaszcza wewnętrznych czynników ryzyka współpracy. Ma to szczególne znaczenie w związku z trudnościami w zapewnieniu kompletności umowy między stronami, wynikającymi z ograniczeń w dostępie do informacji oraz zmienności warunków działania zleceniodawcy i usługodawcy.

\section{Literatura}

Bahli B., Rivard S. [2003], The Information Technology Outsourcing Risk: A Transaction Cost and Agency Theory-based Perspective, ,Journal of Information Technology”, vol. 18, nr 3, https://doi.org/10.1080/0268396032000130214.

Bendor-Samuel B. [1997], Make Sure That Your Outsourcer Delivers on Promises, „Business Communications Review”, vol. 27, nr 8.

Bizon-Górecka J. [2001], Inżynieria niezawodności i ryzyka w zarzadzaniu przedsiębiorstwem, Wydawnictwo OPO, Bydgoszcz.

Buła P. [2015], System zarzadzania ryzykiem w przedsiębiorstwie jako element nadzoru korporacyjnego, Wydawnictwo Uniwersytetu Jagiellońskiego, Kraków.

Corbett M. [2004], The Outsourcing Revolution. Why It Makes Sense and How to Do It Right, Kaplan Publishing, New York.

Gonzalez R., Gasco J., Llopis J. [2009], Information Systems Outsourcing Reasons and Risks: An Empirical Study, „International Journal of Human and Social Sciences”, vol. 4 , nr 3.

Knemeyer M., Corsi T.M., Murphy P.R. [2003], Logistics Outsourcing Relationships: Customer Perspectives, ,Journal of Business Logistics”, vol. 24, nr 1, https://doi. org/10.1002/j.2158-1952.2003.tb00033.x.

Kozina A. [2004], Techniki negocjacji fuzji i przejęć przedsiębiorstw [w:] Organizacje komercyjne i niekomercyjne wobec wzmożonej konkurencji oraz wzrastajacych wymagań konsumentów, red. A. Nalepka, Wyższa Szkoła Biznesu w Tarnowie, Tarnów.

Małkus T. [2013], Czynniki ryzyka wspótpracy z operatorem logistycznym [w:] Wspótczesne kierunki badań w naukach o zarzadzaniu, Badania statutowe Uniwersytetu Ekonomicznego w Krakowie, A. Stabryła i in., Kraków.

Rozporządzenie (WE) nr 648/2005 Parlamentu Europejskiego i Rady z dnia 13 kwietnia 2005 r. zmieniające rozporządzenie Rady (EWG) nr 2913/92 ustanawiające Wspólnotowy Kodeks Celny, Dz.Urz. UE L117.

Stabryła A., Cabała P., Sołtysik M. [2015], Ryzyko i wykonalność projektu [w:] Metodologia projektowania systemów organizacyjnych przedsiębiorstwa, red. A. Stabryła, Wydawnictwo C.H. Beck, Warszawa.

Stuglik A. [2010], Incoterms - formuły ułatwiajace eksport, www.twojakancelaria.com.pl (data dostępu: 29.10.2016).

Szymonik A. [2014], Ryzyko w systemach logistycznych, Zeszyty Naukowe Politechniki Łódzkiej, nr 119, Łódź. 
Tyrańska M. [2008], Obszary ryzyka w zarzadzaniu zasobami ludzkimi w przedsiębiorstwie, „Zeszyty Naukowe Uniwersytetu Ekonomicznego w Krakowie”, nr 772.

Tyrańska M., Walas-Trębacz J. [2007], Monitoring ryzyka personalnego jako uwarunkowanie sukcesu organizacji, Prace i Materiały Wydziału Zarządzania Uniwersytetu Gdańskiego, nr 1, Gdańsk.

Vademecum bezpiecznego spedytora [2013], www.pisil.pl (data dostępu: 29.10.2016).

Weerakkody V., Irani Z. [2010], A Value and Risk Analysis of Offshore Outsourcing Business Models: An Exploratory Study, „International Journal of Production Research”, vol. 48, nr 2, https://doi.org/10.1080/00207540903175160.

Williamson O. [1985], The Economic Institutions of Capitalism, The Free Press, New York.

\section{Risk Management Methodology in Cooperation with a Logistics Service Provider \\ (Abstract)}

The aim of the article is to draw attention to the fact that a company's cooperation with a logistics service provider may also be a source of risk. The efficiency of the enterprise's operations can reduce the risk involved in cooperation with the logistics service provider. For that to happen, however, the origin of a risk must be identified and the strength of its impact on the enterprise's operations determined.

It is possible to identify and reduce the negative effects of cooperation risk with a logistics service provider by applying risk management methodology that will make it possible to identify and diagnose the origin of the place of risk, determine the risk level and select appropriate methods to mitigate or eliminate it. The procedure proposed identifies negative phenomena and enables the proper flow and coordination of information. The risk management methodology is aimed at identifying those aspects of cooperation with the logistics service provider which are incompatible with the standards and criteria established in advance, to ensure a state of flexible cooperation and to reduce the possibility of the costs of the cooperation rising.

Keywords: risk, risk factors, risk management methodology, logistics service provider. 